Far Eastern Entomologist

\begin{tabular}{lll}
\hline Number 439: 14-23 & ISSN 1026-051X (print edition) & October 2021 \\
\hline
\end{tabular}

https://doi.org/10.25221/fee.439.2

http://zoobank.org/References/94DFB950-152B-4496-B6FC-A842E2D1D3CF

\title{
NEW RECORDS OF PTEROMALINAE (HYMENOPTERA: CHALCIDOIDEA, PTEROMALIDAE) FROM IRAN
}

\author{
M. Shojaey ${ }^{1)}$, M. Khayrandish ${ }^{1, *)}$, S. M. Madjdzadeh ${ }^{2)}$, H. Lotfalizadeh ${ }^{3)}$
}

1) Department of Plant Protection, Faculty of Agriculture, Shahid Bahonar University of Kerman, Kerman, Iran. E-mail: M.Shojaey209@gmail.com *Corresponding author: Mohammad Khayrandish,E-mail:m.khayrandish@uk.ac.ir

2) Department of Biology, Faculty of Sciences, Shahid Bahonar University of Kerman, Kerman,Iran.E-mail: madjdzadeh@uk.ac.ir

3) Plant Protection Research Department, East-Azarbaijan Agricultural and Natural Resources Research \& Education Center, AREEO, Tabriz, Iran.E-mail: hlotfalizadeh@gmail.com

Summary. The specimens of the pteromalid wasps (Hymenoptera: Chalcidoidea, Pteromalidae) were caught using Malaise traps and sweeping net in Kerman province of Iran during March 2016 to August 2017. The genus Coelopisthia Förster, 1856 and the species: $C$. areolata Askew, 1980, Homoporus apharetus (Walker, 1839), Norbanus brevicornis Szelenyi, 1974, Pachyneuron gibbiscuta Thomson, 1878, and Sphegigaster pedunculiventris (Spinola, 1808) are recorded for the first time from Iran. The diagnostic characteristics and illustrations are given for the newly recorded species.

Key words: Chalcidoidea, pteromalid wasps, fauna, new records, Palaearctic region.

М. Шоджаей, М. Хайрандиш, С. М. Мадждзаде, Х. Лотфализаде. Новые указания хальцид-птеромалин (Hуmenoptera: Chalcidoidea, Pteromalidae) из Ирана // Дальневосточный энтомолог. 2021. N 439. С. 14-23.

Резюме. Хальциды-птеромалины (Hymenoptera: Chalcidoidea, Pteromalidae) были собраны в иранской провинции Керман с марта 2016 г. по август 2017 г. с использованием ловушек Малеза и кошением сачком. Впервые для Ирана приводятся род Coelopisthia Förster, 1856 и виды C. areolata Askew, 1980, Homoporus apharetus (Walker, 1839), Norbanus brevicornis Szelenyi, 1974, Pachyneuron gibbiscuta Thomson, 1878 и Sphegigaster pedunculiventris (Spinola, 1808). Для этих видов даны краткие диагностические признаки и иллюстрации.

\section{INTRODUCTION}

Pteromalinae Dalman, 1820 (Hymenoptera: Chalcidoidea, Pteromalidae) is a large subfamily in Pteromalidae (Noyes, 2020). It has an almost worldwide distribution with 2330 species within 317 genera. Most species are parasitoids of several insect orders (Noyes, 2020) such as Coleoptera, Lepidoptera and Diptera (Bouček \& Rasplus, 1991). Until now, 100 species belonging to 50 genera of Pteromalinae identified and reported from Iran (Kishani Farahani et al., 2010; Mirtroiu et al., 2011; Hasani et al., 2011; Dehdar \& Madjdzadeh, 2016; 
Mahdavi \& Madjdzadeh, 2013; Mahdavi et al., 2015; Abolhassanzadeh et al., 2017; Moravvej et al., 2018; Rahmani et al., 2019, 2020; Shojaey et al., 2019). The fauna of Iranian Pteromalidae is highly diverse but was poorly studied. Therefore, more specimens need to be collected and identified in different regions of the country. The present study aims to provide new inventory and information of Iranian fauna on pteromalids that have been recently collected as a part of our ongoing project on taxonomy and biodiversity of Iranian Chalcidoidea.

\section{MATERIAL AND METHODS}

During our collecting program of parasitic wasps in southern areas of Kerman province, some pteromalid species were collected by sweep net and Malaise traps. All specimens were collected during March 2016 to August 2017. Among collected material, 111 specimens belonging to Pteromalinae were identified in the present paper. Specimens were preserved in $75 \%$ ethanol until they were mounted on cards and identified. Prior to mounting the specimens were treated with Acetic acid' vapor in order to relaxing the specimens (Noyes, 1982). The morphological terminology and classification follows Gibson (1997) and Bouček (1988), respectively. The identifications were made using Graham's monograph (Graham, 1969) and Bouček \& Rasplus (1991). External morphology was illustrated using an Olympus ${ }^{\mathrm{TM}} \mathrm{SZH}$, equipped with an Omax (18Mp) A35180U3 digital camera. The images were then processed using Combine ZM and Adobe ${ }^{\circledR}$ Photoshop ${ }^{\circledR}$ CS6 programs. The voucher specimens were deposited in the Zoological Museum of Shahid Bahonar University of Kerman, Kerman, Iran (ZMSBUK) and the Department of Plant Protection, Faculty of Agriculture, Shahid Bahonar University of Kerman (DPPBUK).

\section{RESULTS}

Totally, 111 specimens of Pteromalidae belonging to the subfamily Pteromalinae representing 14 genera and 22 species such as Anisopteromalus calandrae (Howard, 1881), Caenocrepis arenicola (Thomson, 1878), Callitula bicolor Spinola, 1811, Catolaccus crassiceps (Masi, 1911), Chlorocytus spicatus (Walker, 1835), Coelopisthia areolata Askew, 1980, Cyrtoptyx lichtensteini (Masi, 1922), Homoporus apharetus (Walker, 1839), H. febriculosus (Girault, 1917), H. fulviventris (Walker, 1835), Norbanus brevicornis Szelenyi, 1974, N. meridionalis (Masi, 1922), Pachycrepoideus vindemmiae (Rondani, 1875), Pachyneuron aphidis (Bouche, 1834), P. gibbiscuta Thomson, 1878, P. leucopiscida Mani, 1939, P. nelsoni Girault, 1928, Peridesmia discus (Walker, 1835), Sphegigaster ineus Mitroiu, 2008, S. nigricornis (Nees, 1834), S. pedunculiventris (Spinola, 1808), Stenoselma nigrum Delucchi, 1956 were collected and identified, of which one genus and five species are new records for Iranian fauna. The newly recorded taxa with short morphological characteristics are listed alphabetically.

\section{Subfamily Pteromalinae Dalman, 1820}

\section{Genus Coelopisthia Förster, 1856}

\section{Coelopisthia areolata Askew, 1980}

Fig. 1

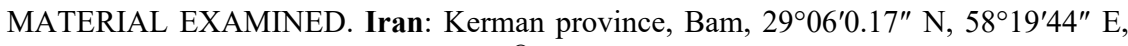
$\mathrm{h}=1111 \mathrm{~m}$, Malaise trap, 22.V-4.VII 2017, 1 \% , leg. M. Purrezaali; Jiroft, Dalfard, 29 $01^{\prime} 31.4^{\prime \prime}$ N, 57³6'56.1" E, h=2390m), Malaise trap, 17.VI-27.VIII 2017, 2 ㅇ, leg. S.M. Madjdzadeh. 
SHORT DESCRIPTION. Body dark blue; clypeus finely reticulate, clypeal margin symmetric, antennal formula $1,1,2,6,3$, the second anelli subquadrate, clava rounded at apex, face protuberant at antennal insertion, scape not reaching median ocellus; mesosoma slightly flattened, pronotal collar with a weakly elevated and rounded anterior margin and with a shining posterior strip, notauli incomplete, propodeal plicae complete and median area between them sculptured, propodeum with short nucha, entire thoracic pleura except upper mesepimeron reticulate; fore wing apical fringe reduced in anterior part, marginal vein slender, postmarginal vein about as long as stigmal vein; metasoma sessile and round, basal tergite posterior edge weakly sinuate.

DISTRIBUTION IN IRAN. Kerman province (new record for Iran).

GENERAL DISTRIBUTION. Palaearctic region (Noyes, 2020).

HOSTS. The hosts of this species are unknown.

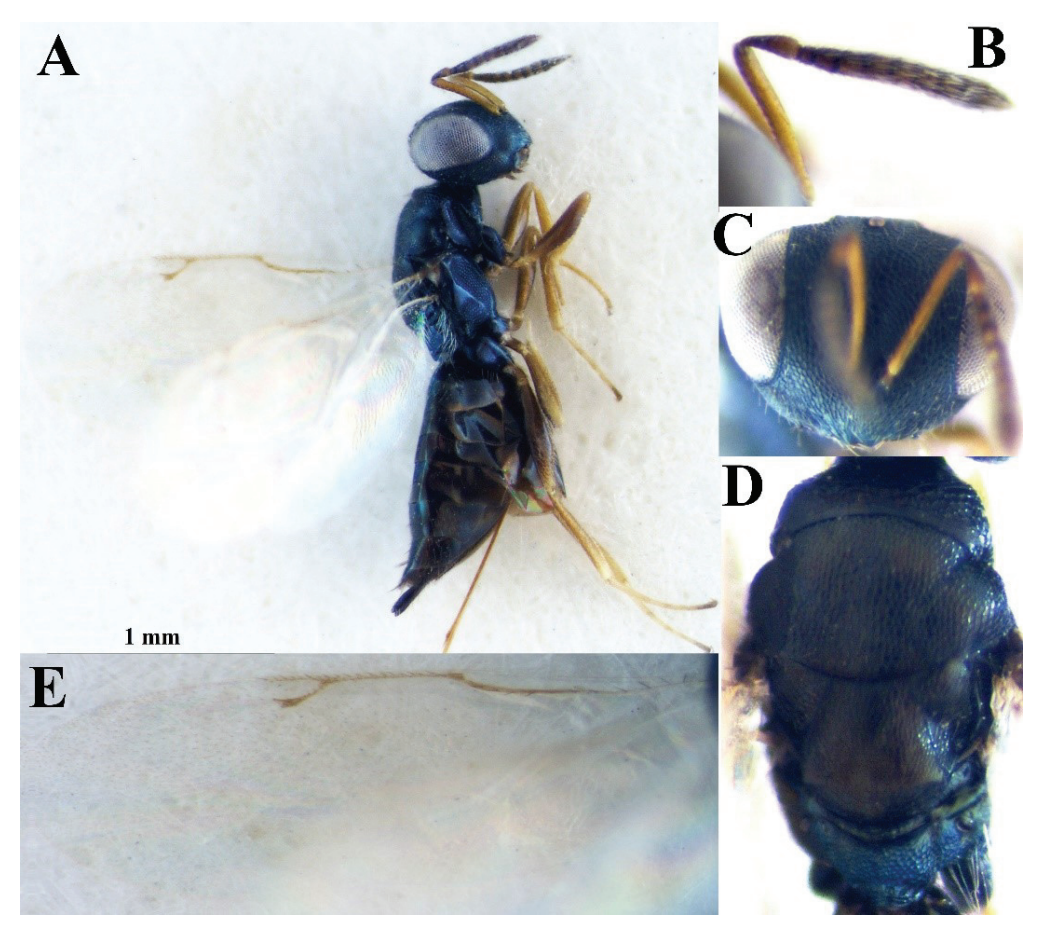

Fig. 1. Coelopisthia areolata Askew, 1980, female. A - body, lateral view; B - antenna; $\mathrm{C}$ - head, frontal view; D - mesosoma, dorsal view; E - fore wing.

\section{Genus Homoporus Thomson, 1878}

\section{Homoporus apharetus (Walker, 1839)}

Fig. 2

MATERIAL EXAMINED. Iran: Kerman province, Bam, $29^{\circ} 06^{\prime} 0.17^{\prime \prime} \mathrm{N}, 58^{\circ} 19^{\prime} 44^{\prime \prime} \mathrm{E}$ $\mathrm{h}=1111 \mathrm{~m}$, Malaise trap, 22.V-3.VI 2017, 19, leg. M. Purrezaali; the same locality and collector, 4.VII-26.VIII 2017, 1으. Leg.: M. Purrezaali; Jiroft, Dalfard, 2901'31.4" N, 57³6'56.1" E, h=2390m, Malaise trap, 17.VI-27.VIII 2017, 2ㅇ, leg. S.M. Madjdzadeh. 
SHORT DESCRIPTION. Head and thorax dark blue; occipital carina absent, antennal formula $1,1,2,6,3$, clava distinctly acute apically, 1 st club suture rather distinct, scape not reaching median ocellus, both mandible 3 dentate, clypeal margin without teeth, pronotum as broad as mesoscutum, notauli incomplete, propodeum sculptured, median carina absent, prepectus triangular and larger than tegulae, hind tibia with one spur; fore wings infuscate and not completely pilose, marginal vein widened either throughout and about 1.25 times as long as stigmal vein, postmarginal vein much longer than marginal vein; metasoma dark brown and sessile.

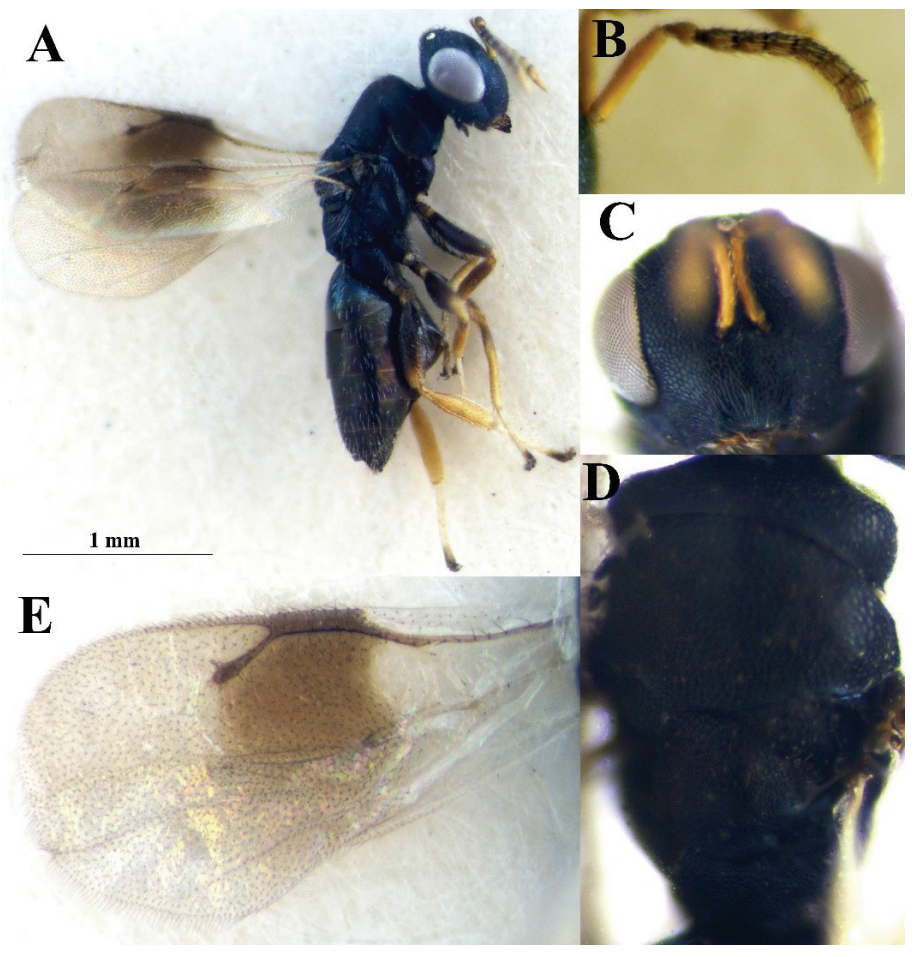

Fig. 2. Homoporus apharetus (Walker, 1839), female. A - body, lateral view; B - antenna; $\mathrm{C}$ - head, frontal view; D - mesosoma, dorsal view; E - fore wing.

DISTRIBUTION IN IRAN. Kerman province (new record for Iran).

GENERAL DISTRIBUTION. Palaearctic region (Noyes, 2020).

HOSTS. The hosts of this species in Iran are unknown. Homoporus apharetus is reported mainly from species of Eurytomidae (Hymenoptera) such as Tetramesa brevicornis (Walker, 1832) and Tetramesa linearis (Walker, 1832) (Noyes, 2020).

\section{Genus Norbanus Walker, 1843}

\section{Norbanus brevicornis Szelenyi, 1974}

Fig. 3

MATERIAL EXAMINED. Iran: Kerman province, Jiroft, Mijan, Koldan, 28 $44^{\prime} 27.8^{\prime \prime}$

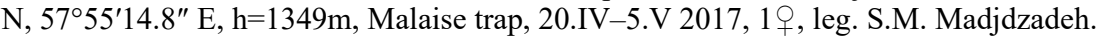


SHORT DESCRIPTION. Body dark blue; globose head with large rounded temples, antennal formula $1,1,2,6,3$, funicular segments from 3rd to 6th subquadrate, claval segments apparently fused; club pointed bearing a short stocky spicula, antennae short and inserted lower than the center of face, clypeal margin symmetric; pronotum short and about as broad as mesoscutum, mesoscutum and scutellum conspicuous reticulate, notauli incomplete, propodeum sculptured and without median carina, either thoracic pleura except narrow anterior edge of mesepimeron regularly reticulate, prepectus much shorter than tegula, hind tibia with 2 spurs; fore wings completely pilose and speculum absent, basal cell uniformly hairy, marginal vein slender and much longer than stigmal vein; metasoma sessile.

DISTRIBUTION IN IRAN. Kerman province (new record for Iran).

GENERAL DISTRIBUTION. Palaearctic region (Noyes, 2020).

HOSTS. The hosts of this species are unknown.

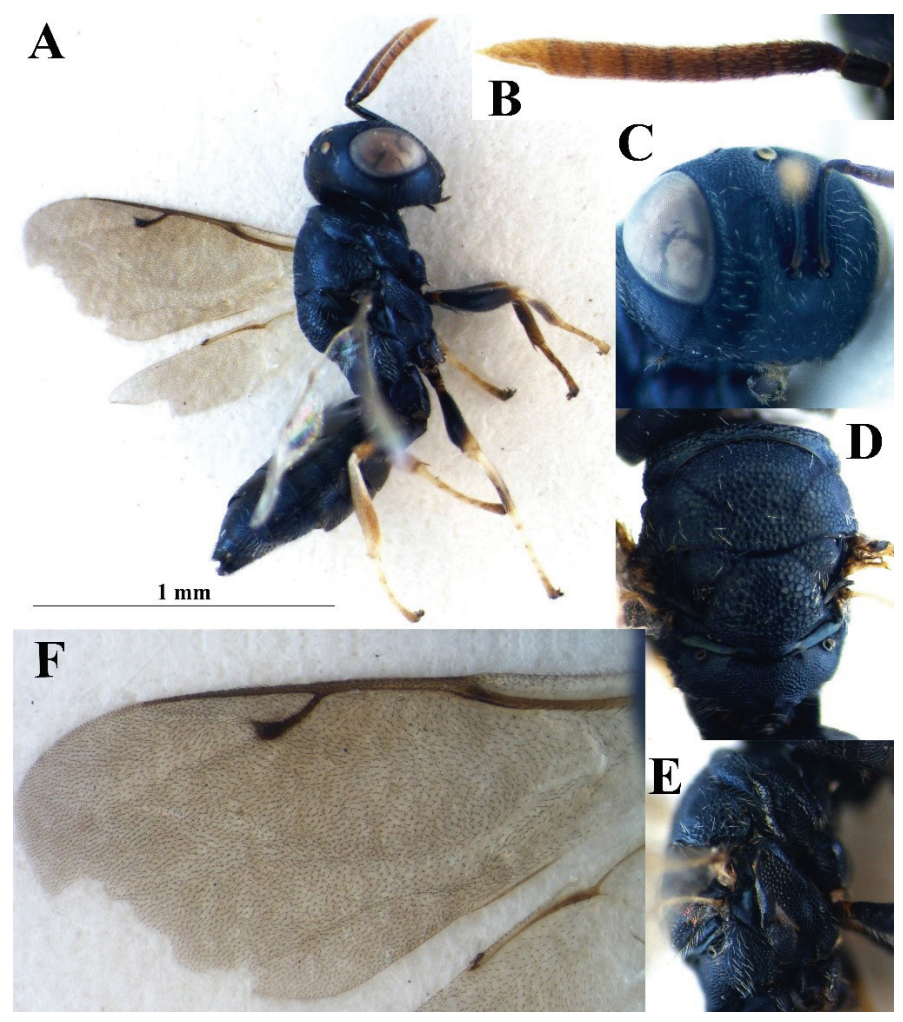

Fig. 3. Norbanus brevicornis Szelenyi, 1974, female. A - body, lateral view; B - antenna; $\mathrm{C}$ - head, frontal view; D - mesosoma, dorsal view; $\mathrm{E}$ - the same, lateral view; $\mathrm{F}$ - fore wing.

\section{Genus Pachyneuron Walker, 1833}

\section{Pachyneuron gibbiscuta Thomson, 1878}

Fig. 4

MATERIAL EXAMINED. Iran: Kerman province, Jiroft, Bahram Abad, $28^{\circ} 19^{\prime} 00.5^{\prime \prime} \mathrm{N}$, 57²37'08.5" E, h=679m, Malaise trap, 9-29.IV 2017, 1웅 leg. S.M. Madjdzadeh; Kahnuj, 


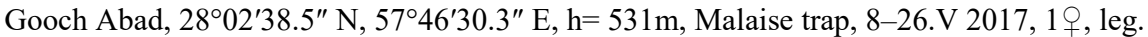
M. Changizi; Kahnuj, Tomgoran, $28^{\circ} 01^{\prime} 56.7^{\prime \prime}$ N, $57^{\circ} 44^{\prime} 37.4^{\prime \prime}$ E, h=537m, swept on Medicago sativa, 5.IV 2017, 1 \%, leg. M. Changizi; Kahnuj, Gooch Abad, $28^{\circ} 02^{\prime} 07.8^{\prime \prime}$ N, 5745'34.8" E, $\mathrm{h}=528 \mathrm{~m}$, swept on Medicago sativa, 16.IX 2016, 2ㅇ, leg. M. Changizi.

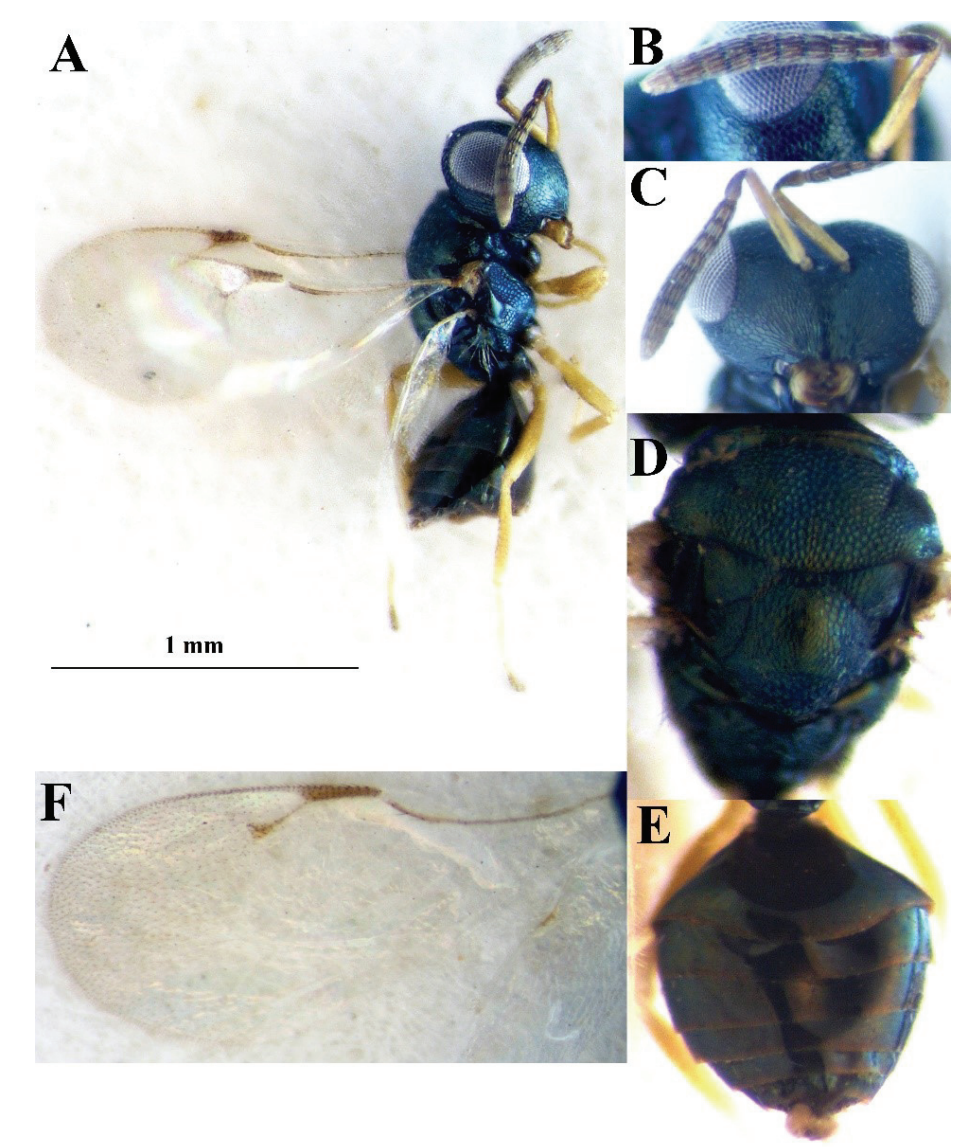

Fig. 4. Pachyneuron gibbiscuta Thomson, 1878, female. A - body, lateral view; B - antenna; $\mathrm{C}$ - head, frontal view; D - mesosoma, dorsal view; $\mathrm{E}$ - metasoma, dorsal view; $\mathrm{F}$ fore wing.

SHORT DESCRIPTION. Body blue-green; metasoma with some bronze reflections; antennal formula $1,1,2,6,3$, anelli obviously transverse, all funicular segments subquadrate, clava without conspicuous micropilosity area, clypeal margin symmetric, occiput without carina; mesosoma dorsally moderately convex, mesoscutum and scutellum reticulate, notauli incomplete, propodeum with short nucha, propodeal plicae complete, entire thoracic pleura except upper mesepimeron reticulate; fore wing apical fringe, marginal vein widened distad, postmarginal vein much longer than marginal vein; metasoma on distinct petiole, dorsal part of petiole almost smooth, margin of first tergite regularly arched.

DISTRIBUTION IN IRAN. Kerman province (new record for Iran).

GENERAL DISTRIBUTION. Palaearctic region (Noyes, 2020). 
HOSTS. The hosts of this species in Iran are unknown. Pachyneuron gibbiscuta is reported mainly from species of Aphididae (Hemiptera) such as Myzus cerasi (Fabricius, 1775) (Noyes, 2020).

\section{Genus Sphegigaster Spinola, 1811}

\section{Sphegigaster pedunculiventris (Spinola, 1808)}

Fig. 5

MATERIAL EXAMINED. Iran: Kerman province, Kahnuj, Tomgoran, 28 $01^{\prime} 48.2^{\prime \prime}$ N, $57^{\circ} 44^{\prime} 22.2^{\prime \prime} \mathrm{E}, \mathrm{h}=528 \mathrm{~m}$, Malaise trap, 5-11.IV 2017, 10, leg. M. Changizi.

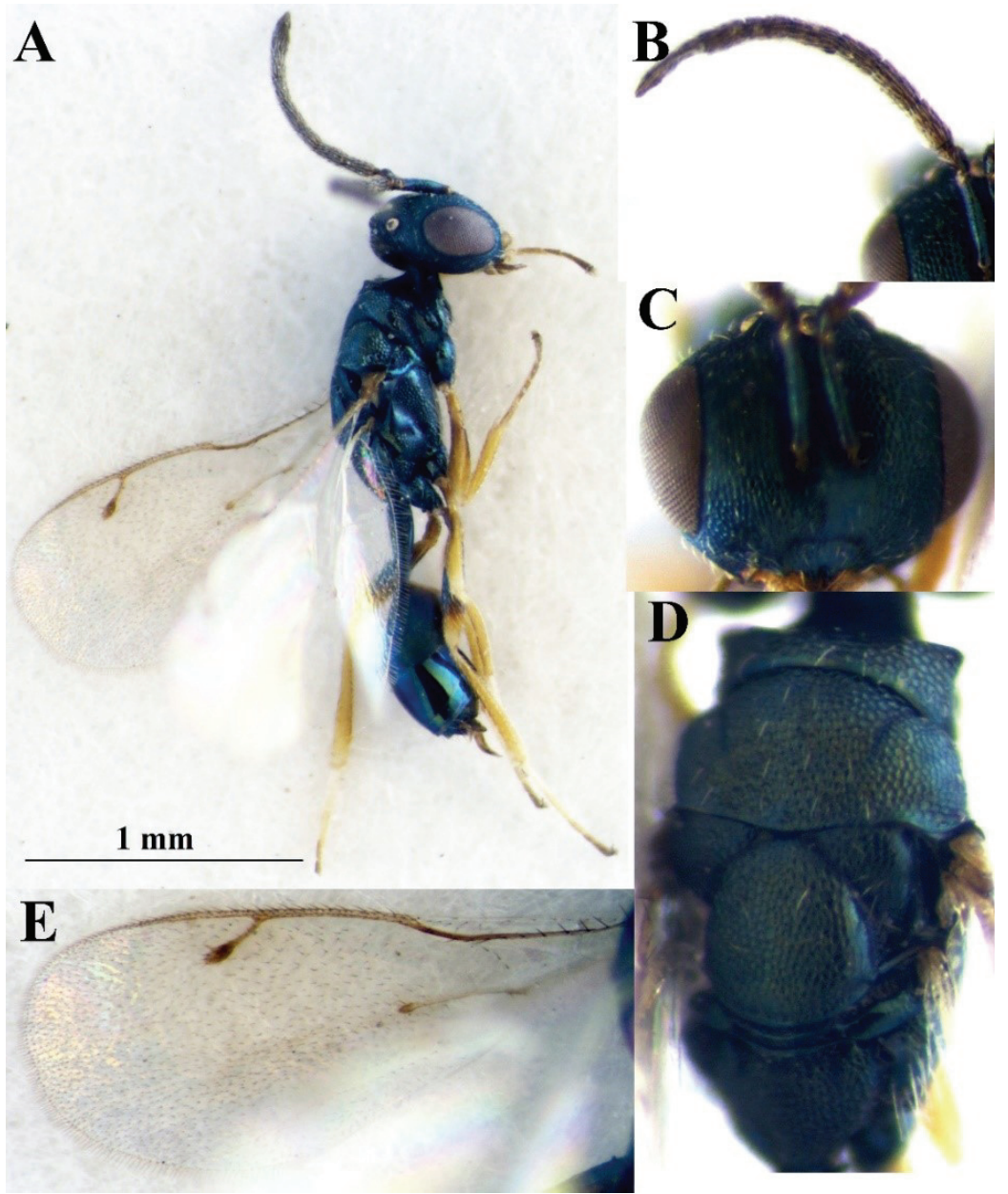

Fig. 5. Sphegigaster pedunculiventris (Spinola, 1808), male. A - body, lateral view; B antenna; $\mathrm{C}$ - head, frontal view; D - mesosoma, dorsal view; $\mathrm{E}$ - fore wing. 
SHORT DESCRIPTION. Body either bright blue; antennal formula 1, 1, 2, 6, 3, antenna inserted below center of face, all funicular segments longer than wide, suture of clava not oblique, clypeal margin with 2 sharply teeth; mesosoma convex, pronotum distinctly margined, notauli incomplete, propodeum without median carina; fore wing with dense pubescence beyond speculum, marginal vein not thickened; metasoma on distinct petiole, petiole longer than propodeum and dorsally with distinct dense reticulation, tergite 1 and 2 large, middle part of posterior margin of $1^{\text {st }}$ abdominal tergite truncate.

DISTRIBUTION IN IRAN. Kerman province (new record for Iran).

GENERAL DISTRIBUTION. Palaearctic region (Noyes, 2020).

HOSTS. The hosts of this species in Iran are unknown. Sphegigaster pedunculiventris is reported mainly from species of Agromyzidae (Diptera) such as Agromyza aeneoventris Fallén, 1823, Melanagromyza aeneoventris (Fallén, 1923), Melanagromyza albocilia Hendel, 1931, Melanagromyza lappae (Loew, 1850), and Napomyza lateralis (Fallén, 1823) (Noyes, 2020).

\section{DISCUSSION}

According to present study, the total number of pteromalid species increased to 149 species in 69 genera in Iran. The genus Coelopisthia is recorded for the first time from Iran including a single species, C. areolata. Also Homoporus apharetus, Norbanus brevicornis, Pachyneuron gibbiscuta and Sphegigaster pedunculiventris are new record for the fauna of Iran. All these species except $P$. gibbiscuta and $S$. pedunculiventris have not been recorded from neighboring countries and distributed only in the Palaearctic region. Pachycrepoideus vindemmiae and Pachyneuron aphidis are cosmopolitan species. No host record is documented for $C$. areolata and $N$. brevicornis yet and other species have been known as parasitoids of some species of Coleoptera, Lepidoptera, Diptera, Hemiptera and Hymenoptera (Noyes 2020).

\section{ACKNOWLEDGMENTS}

This research was supported by Shahid Bahonar University of Kerman and EastAzarbaijan Agricultural and Natural Resources Research \& Education Center, which is greatly appreciated. Our special thanks are expressed to Mr. M. Purrezaali and Mrs. M. Changizi for helping us in sample collection. The authors are grateful to anonymous reviewers for their valuable comments and recommendations on the earlier version of this paper.

\section{REFERENCES}

Abolhassanzadeh, F., Lotfalizadeh, H. \& Madjdzadeh, S.M. 2017. Updated checklist of Pteromalidae (Hymenoptera: Chalcidoidea) of Iran, with some new records. Journal of Insect Biodiversity and Systematics, 3(2): 119-140.

Bayegan, Z.A, Lotfalizadeh, H., Zargara, M.R. \& Pooraiiouby, R. 2014. New record of the genus and species Callitula ferrierei (Bouček) (Hymenoptera: Pteromalidae) from Iran. Journal of Crop Protection, 3(2): 125-128.

Bouček, Z. 1988. Australasian Chalcidoidea (Hymenoptera). A biosystematic revision of genera of fourteen families, with a reclassification of species. Wallingford (UK): CAB International. $832 \mathrm{pp}$

Bouček, Z. \& Rasplus, J.Y. 1991. Illustrated key to West-Palearctic genera of Pteromalidae (Hymenoptera: Chalcidoidea). Paris: Institut National de la Recherche Agronomique. $140 \mathrm{pp}$. 
Dehdar, K. \& Madjdzadeh, S.M. 2013. A contribution to the knowledge of the pteromalid wasps (Hymenoptera: Chalcidoidea: Pteromalidae) of Kurdistan province, Western Iran including new records. Biharean Biologist, 7(2): 90-93.

Dehdar, K. \& Madjdzadeh, S.M. 2016. Pteromalidae (Hymenoptera: Chalcidoidea) from Kordestan province, western Iran. Far Eastern Entomologist, 315: 11-20.

Ebrahimi, E. 2014. Parasitoid and hyperparasitoid wasps of scale insects in Hayk Mirzayans Insect Museum, Iran. Journal of Entomological Society of Iran, 34(1): 73-83.

Gibson, G.A.P. 1997. Morphology and Terminology. P. 16-44. In: Gibson, G.A.P.; Huber, J.T.; Woolley, J.B. (Eds). Annotated keys to the genera of Nearctic Chalcidoidea (Hymenoptera). Chapter 2. National Research Council of Canada, NRC Research Press, Ottawa, Canada.

Graham, M.W.R. de V. 1969. The Pteromalidae of North-Western Europe (Hymenoptera: Chalcidoidea). The Bulletin of the British Museum (Natural History), 16: 1-908.

Haeselbarth, E. 1983. Determination list of entomophagous insects. No. 11. Bulletin Section Regionale Ouest Palaearctique. Organisation Internationale de Lutte Biologique, 12(7): $1-62$.

Hasani, A. \& Madjdzadeh, S.M. 2012. Contribution to the knowledge of the Pteromalidae (Hymenoptera: Chalcidoidea) from Khorasan Razavi province, Northeastern Iran. Iranian Journal of Animal Biosystematics, 8(1): 57-69.

Hasani, A., Mitroiu, M.D. \& Madjdzadeh, S.M. 2011. New records of Pteromalidae (Hymenoptera: Chalcidoidea) from Northeastern Iran. Acta Zoologica Bulgarica, 63(3): 323 325.

Kazemi, F., Talebi, A.A., Fathipour, Y. \& Moharramipour, S. 2004. Host stage preference and functional response of Anisopteromalus calandrae (Hymenoptera: Pteromalidae), a larval parasitoid of Callosobruchus maculatus (Coleoptera: Bruchidae) on chickpea in laboratory conditions. P. 29. In: Proceeding of the 16th Iranian Plant Protection Congress, 28 August-1 September 2004, University of Tabriz, Iran.

Kazemi, F., Talebi, A.A. \& Fathipour, Y. 2010. The reproduction and population growth parameters of Anisopteromalus calandrae (Hymenoptera: Pteromalidae), a parasitoid of Callosobruchus maculatus (Coleoptera: Bruchidae). Journal of Entomological Society of Iran, 29(2): 1-10.

Kishani Farahani, H., Goldansaz, S.H., Sabahi, G. \& Baur, H. 2010. First report of Pachycrepoideus vindemmiae (Hymenoptera: Pteromalidae) from Iran. Journal of Entomological Society of Iran, 29(2): 117-118.

Lotfalizadeh, H. 2015. Review of the Iranian Pteromalinae with spiculated antennae, and description of a new species of Norbanus Walker (Hymenoptera: Chalcidoidea, Pteromalidae. Zootaxa, 4013(3): 428-434. DOI: https://doi.org/10.11646/zootaxa.4013.3.6

Lotfalizadeh, H. \& Gharali, B. 2008. Pteromalidae (Hymenoptera: Chalcidoidea) of Iran: New records and a preliminary checklist. Entomofauna, 29(6): 93-120.

Lotfalizadeh, H. \& Hosseini, F. 2014. Chalcidoid parasitoids (Hymenoptera) of Etiella zinckenella (Treitschke) (Lepidoptera: Pyralidae) on Sophora alopecuroides L. in Iran. North-western Journal of Zoology, 10(2): 251-258.

Lotfalizadeh, H., Karimpour, Y., Delvare, G. \& Rasplus, J.Y. 2020. Chalcidoidea (Hymenoptera) obtained from common reed, Phragmites australis (Cav.) Trin. ex Steud. (Poaceae) in Iran with new records and descriptions of two new species. European Journal of Taxonomy, 710: 1-35. DOI: https://doi.org/10.5852/ejt.2020

Lotfalizadeh, H., Pourhaji, A. \& Zargaran, M.R. 2015. Hymenopterous parasitoids (Hymenoptera: Braconidae, Eulophidae, Pteromalidae) of the alfalfa leafminers in Iran and their diversity. Far Eastern Entomologist, 288: 1-24. 
Mahdavi, M. \& Madjdzadeh, S.M. 2013. Contribution to the knowledge of Chalcidoidea (Pteromalidae and Eupelmidae) of Iran. North-western Journal of Zoology, 9(1): 94-98.

Mahdavi, M., Madjdzadeh, S.M. \& Mitroiu, M.D. 2015. Pteromalidae (Hymenoptera: Chalcidoidea) associated with plant galls in the south-eastern Iran, with three new records. Journal of Insect Biodiversity and Systematics, 1(1): 47-54.

Mitroiu, M.D., Abolhassanzadeh, F. \& Madjdzadeh, S.M. 2011. New records of Pteromalidae (Hymenoptera: Chalcidoidea) from Iran, with description of a new species. North-western Journal of Zoology, 7(2): 243-249.

Moravvej, S.A., Lotfalizadeh, H. \& Shishehbor, P. 2018. A contribution to the study of Pteromalidae (Hymenoptera: Chalcidoidea) of Khuzestan in southwestern Iran. Journal of Insect Biodiversity and Systematics, 4(2): 91-97.

Nazemi Rafie, J., Alipanah, V. \& Lotfalizadeh, H. 2011. Report of five species of Pteromalidae (Hymenoptera: Chalcidoidea) new for the Iranian fauna. Journal of Crop Protection, 3(3): 211-222.

Noyes, J.S. 1982. Collecting and preserving chalcid wasps (Hymenoptera: Chalcidoidea). Journal of Natural History, 16: 315-334.

Noyes, J.S. 2020. Universal Chalcidoidea Database. The Natural History Museum, London. Available at: http://www.nhm.ac.uk/ chalcidoids (accessed 20th September 2020).

Rahmani, Z., Rakhshani, E., Lotfalizadeh, H. \& Mokhtari, A. 2019. Two small genera, Ischyroptyx Delucchi and Novitzkyanus Bouček (Hymenoptera: Pteromalidae) new to fauna of Iran. Oriental insects. DOI: https://doi.org/10.1080/00305316.2019.1697767

Rahmani, Z., Rakhshani, E., Lotfalizadeh, H. \& Mokhtari, A. 2020. First records of the genera Psilocera Walker, 1833 and Stinoplus Thomson, 1878 (Hymenoptera: Pteromalidae) in Iran. Journal of Insect Biodiversity and Systematics, 6(3): 213-221.

Rakhshani, E., Talebi, A.A, Sadeghi, E., Kavallieratos, N.G. \& Rashed, A. 2004. Sesonal parasitism and hyperparasitism of valnus aphidm Chromaphis juglandicola (Homoptera: Aphididae) in Tehran province. Journal of Entomological Society of Iran, 23(2): 1-11.

Shojaey, M., Khayrandish, M., Madjdzadeh, S.M. \& Lotfalizadeh, H. 2019. First record of Caenocrepis arenicola (Thomson, 1878) (Hymenoptera: Pteromalidae) from Iran. Journal of Insect Biodiversity and Systematics, 5(2): 121-126. 